Article

\title{
Aeolian Material Migration in Transbaikalia (Asian Russia)
}

\author{
Olga Bazhenova ${ }^{1,2, *}$, Dmitrii Kobylkin ${ }^{1}$ and Elizaveta Tyumentseva ${ }^{3}$ \\ 1 V.B. Sochava Institute of Geography SB RAS, 664033 Irkutsk, Russia; agrembrandt@inbox.ru \\ 2 Irkutsk Scientific Center, Siberian Branch of the Russian Academy of Sciences, 664033 Irkutsk, Russia \\ 3 Department of Geography, Life Safety and Methodology, Irkutsk State University, 664033 Irkutsk, Russia; \\ tumencev@irk.ru \\ * Correspondence: bazhenova@irigs.irk.ru; Tel.: +7-3952426920
}

Received: 25 November 2018; Accepted: 2 January 2019; Published: 14 January 2019

check for updates

\begin{abstract}
We revealed regional features of functioning of a large Transbaikalian aeolian morphodynamic system. Natural pre-conditions, current realities and factors of development of aeolian processes are investigated. The paper considers regularities of spatial distribution of deflation, transit, and aeolian accumulation zones. Main directions of aeolian migration of matter are determined. Pulsating nature of aeolian processes development in Holocene has been established. Identified are intrasecular cycles and Holocene dynamics of aeolian processes. We identified intrasecular (11, 27-35 years old), secular (80 year old) and Holocene (500, 2000 year old) cycles of aeolian process dynamics. The paper shows the influence of anthropogenic activity on the activation of aeolian migration of material for the historical period. It presents an overview of extreme aeolian events. Regionalization of Transbaikalia was carried out according to the degree of probable desertification of the territory due to development of aeolian processes. Areas of catastrophic manifestation of processes are highlighted. The results of long-term experimental observations of deflation and aeolian accumulation are presented. Particular attention is paid to the characteristics of the aeolian corridors. The important role of aeolian processes in the intensive material transport from Transbaikalia to the south and southeast to neighboring regions of Mongolia and China is shown.
\end{abstract}

Keywords: aeolian processes; material migration; deflation basins; dunes; deflation; aeolian accumulation; mobile sands; aeolian corridors; Transbaikalia

\section{Introduction}

Transbaikalia is an ancestral land of Russia which is located almost in the center of the Asian continent (Figure 1). Transbaikalia is characterized by a sharply continental climate, a difficultly dissected relief, a large variety of landscapes, and dangerous natural processes, which sometimes acquire a catastrophic extreme character. Due to its negative environmental impact on human activity, the role of aeolian processes is particularly noteworthy, manifesting in the occurrence of dust storms, in the formation of focal areas of moving loose sands, and in deflationary soil degradation on croplands and pastures.

The studies of aeolian processes have been performed in different parts of this vast territory by now. The processes are most thoroughly investigated in Western Transbaikalia. V.A. Obruchev [1] wrote about the aeolian sands spreading in Western Transbaikalia and about the need for urgent measures to stabilize them back in the 17th century. In the 1950s-1960s, mobile and poorly overgrown sands occupied an area of about $1000 \mathrm{~km}^{2}$, including croplands and pastures subjected to deflation more than $3000 \mathrm{~km}^{2}$ [2]. The aeolian processes obtain high intensity in the southeastern Transbaikalia, which is part of the Central Asian physiographic region [3]. This area represents one of the globally 
significant centers of intense aeolian activity [4]. The functioning of the aeolian systems of Central Asia makes a significant contribution to the emission of dust into the global atmosphere [5]. The aeolian processes here are spatially ordered [6-9]. The purpose of this manuscript is to summarize the materials of long-term research of aeolian processes in the region and to show the contribution of an individual subsystem to the function of a single large regional aeolian system of Transbaikalia. At the same time, the priority tasks were the assessment of the impact of the landscape system on land cover, ecological condition of this vast territory, and the identification of its role in the migration of the matter in Central Asia.

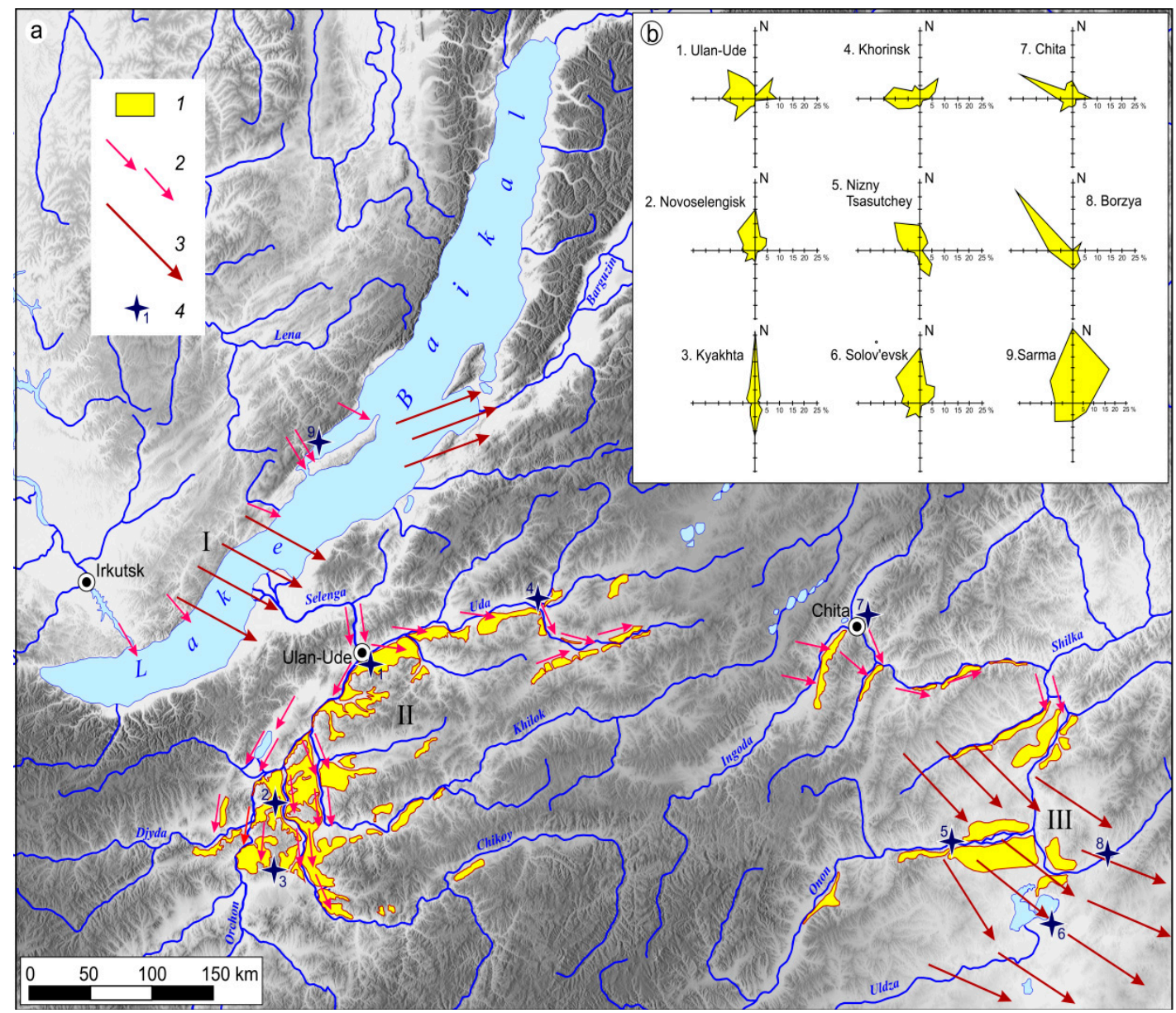

Figure 1. Distribution of aeolian sediments and main streams of aeolian matter transfer in the territory of Transbaikalia (a): 1—areas occupied by aeolian, aeolian-deluvial, and aeolian-proluvial sediments; 2-main wind corridors in depressions, river valleys; 3-extensive wind corridors over the plains and water surfaces of large bodies of water; 4-weather stations and their number; districts: I-Baikal'skii, II-Selenginskii, III-Daurskii; (b) —average annual wind roses of weather stations (numbers correspond with the diagram).

\section{Data and Methods}

The study is based on the results of long-term experimental observations of the aeolian matter migration at the field stations of the V.B. Sochava Institute of Geography SB RAS. Aeolian material was collected in dust collectors on the reference profiles, representative for the semi-arid areas of the south of Siberia. The dust collectors were located at different distances from the main sources of deflation, taking into account the prevailing winds, nature of the vegetation, sedimentology, relief, and features of anthropogenic impact. The observations were conducted year-round. Fine particles brought by the wind here was extracted every month, weighed, and analyzed. The data were taken from the literature and calculated using the equations of S.J. Wilson and R.U. Cook [10]. We have proposed a module 
of aeolian migration of matter (A) measured by the amount ( $\mathrm{g}$, $\mathrm{kg}$, tons) of material transported by the wind per unit area $\left(\mathrm{m}^{2}, \mathrm{~km}^{2}\right.$, ha) per year as one of the main indicators of the intensity of aeolian processes. The presence of aeolian material has enabled us to suggest the module of aeolian migration (A) as one of the main indicators of the aeolian processes intensity, measured by the amount of material, transported by the wind per unit area $\left(\mathrm{g} / \mathrm{m}^{2}\right.$ for $\left.\mathrm{t} / \mathrm{km}^{2}\right)$ per year. Using the index allows estimating soil loss from deflation. Other important parameters of aeolian activity, considered in the article for its comparative characteristics within each section are the wind deflation potential (WDP), the climatic index of deflation (C), and the number and duration of dust storms. The deflationary wind potential $\left(r_{j}\right)$ was determined by the equation

$$
r_{j}=0.001 \mathrm{~V} 3 \mathrm{i} \mathrm{f}_{\mathrm{i}}
$$

where $\mathrm{V}$ is the average wind speed in the speed group $i ; f_{i}$ is the duration expressed as a percentage of the total observation period in the $\mathrm{j}$ direction [10]. Wind loads for each month were represented as the sum of the corresponding values for each direction (eight points). The annual deflationary potential was summed up by months. The data for the calculations were indicators of repeatability of directions, $\%$ and average wind speed, $\mathrm{m} / \mathrm{s}$, taken from the table "Wind by eight points" of the Meteorological monthly of the Irkutsk and Transbaikalian Interregional Territorial Meteorological services (Issue 22, 23) from 2000 to 2018. The number of dust storms correlates with deflation climatic factor $(C)$ which is the most important indicator determining the potential danger of the development of aeolian processes proposed for climate conditions of the north American steppes [6]. Thereat we took into account the average wind speed $\mathrm{V}$, the annual rainfall $\mathrm{H}$, the annual average temperature $\mathrm{T}$, related by the following relationship: $\mathrm{C}=10^{2} \cdot \mathrm{V}^{3} /(\mathrm{H} / \mathrm{T}+10)^{2}$. The index examination confirmed the possibility of its use for semi-arid regions of Russia [6]. The morphology of aeolian forms was studied during expeditions.

To clarify the processes in the Holocene we researched sections of aeolian deposits with carbon dating of buried soils. The study used GIS technology, which made it possible to determine the morphological characteristics of aeolian relief and their change over time. Comparing the obtained results with hydro-meteorological data we identified the main directions of aeolian migration of matter.

\section{Results and Discussion}

\subsection{Natural Prerequisites for Development of Aeolian Processes}

The current course of deflation in Transbaikalia is a result of combination of intensive economic use of the territory and favorable climatic parameters. The indispensable conditions for soil deflation are: presence of wind speed sufficient for blowing soil particles and not grassed dry, sprayed or finely aggregated soils. The aforementioned conditions characterize the steppes of Transbaikalia where deflation is facilitated by the light mechanical composition of soil, loosening of uppermost sediment layer, and its powderiness.

Long-term stationary research of aeolian processes showed their close dependence on landscape-climatic factors. It has been established that the module of aeolian migration of matter, determined experimentally and reflecting the intensity of aeolian processes, is proportional to the climatic index of deflation (C). The annual values of the climatic index of deflation in Transbaikalia vary from 1.4 to 10 , in some years the maximum values reach 20-25 (south-western coast of Lake Baikal and southern Transbaikalia).

Number of dust storms $(\mathrm{N})$ correlates well with the actual volume of the transported matter. The maximum number of dust storms is confined to areas with unaffected sandy covers and with light loamy soils. Thus, in the southern regions of Transbaikalia their number reaches 30 or more (see Table 1). 
Table 1. Climatic indices that determine the intensity of matter migration.

\begin{tabular}{|c|c|c|c|c|c|c|c|c|}
\hline \multirow[t]{2}{*}{ Station } & \multirow{2}{*}{$\begin{array}{c}\text { Number } \\
\text { of Dust } \\
\text { Storms, (N) }\end{array}$} & \multicolumn{2}{|c|}{ Wind Speed $(\mathrm{V}, \mathrm{m} / \mathrm{s})$} & \multirow{2}{*}{$\begin{array}{l}\text { Deflationary } \\
\text { Wind Potential, } \\
\text { Annual }\left(r_{j}\right)\end{array}$} & \multirow{2}{*}{$\begin{array}{l}\text { Annual } \\
\text { Precipitation, } \\
\text { (H, mm) }\end{array}$} & \multirow{2}{*}{$\begin{array}{l}\text { Precipitation } \\
\text { of the Cold } \\
\text { Period (mm) }\end{array}$} & \multicolumn{2}{|c|}{$\begin{array}{c}\text { Climatic Index of } \\
\text { Deflation (C) }\end{array}$} \\
\hline & & Mean & Max & & & & Mean & Max \\
\hline Bolshoe Goloustnoe & 3 & 4.5 & 27 & 110 & 261 & 24 & 10 & 18 \\
\hline Sarma & 0 & 3.1 & 45 & 115 & 148 & 13 & 6 & 13 \\
\hline Khuzhir & 3 & 3.3 & 28 & 85 & 139 & 14 & 13 & 24 \\
\hline Ivolginsk & & 2.2 & 20 & 20 & 202 & 19 & 2 & 5 \\
\hline Tarbagatai & 20 & 2.2 & 33 & 53 & 205 & 20 & 2.5 & 7 \\
\hline Ulan-Ude & 4 & 2.4 & 24 & 27 & 210 & 28 & 2.5 & 8 \\
\hline Gusinoozersk & 17 & 2.0 & 32 & 61 & 192 & 14 & 1.8 & 10 \\
\hline \multicolumn{9}{|c|}{ Daurskii region } \\
\hline Solov'evsk & 32 & 3.4 & 21 & 80 & 288 & 16 & 2 & 7 \\
\hline Borzya & 5 & 3.1 & 24 & 96 & 342 & 17 & 1.4 & 6 \\
\hline Zabaikal'sk & 8 & 3.5 & 22 & 82 & 292 & 27 & 5.2 & 15 \\
\hline
\end{tabular}

Dust storms have not been observed in Sarma in the last decade due to covering of the slope surface by deflationary debris; there is no easily waving material.

The longest and strongest dust storms occur in the spring in April-May. At all the stations taken into consideration, the maximum monthly average speed is observed during this period. This annual cycle of wind speed is determined by the circulation of air conditions. Furthermore, a decrease in the number of calm days is observed in Transbaikalia for the period from 1936 to 2007 (as exemplified by Chita-increased by five times, and by two times in Borzya). In recent years, the number of winter dust storms has increased, since in the southern steppe and forest-steppe regions, duration of snow cover is the shortest in the Transbaikalia. In some years the stable snow cover is not established. In the western part of Transbaikalia, there was a decrease in the duration of snow cover. The most significant decrease is observed in the areas adjacent to Baikal. According to data from open meteostations during the period of maximum accumulation of snow the average perennial snow cover varied from 2 to 34 . Snow cover in Transbaikalia corresponds to the distribution of winter precipitation (in November-February). The amount of rainfall decreases towards Central Transbaikalia. The thinnest snow cover is typical for the central and southern forest-steppe and steppe regions. At some stations in the southern regions there was no snow in February in 30\% of cases.

Analysis of the wind regime of the reference areas showed that active winds, i.e., deflation winds account for $20 \%$ on average in the steppes of Transbaikalia annually. They are mostly observed in spring and early summer. That is a period with days when strong wind, causing the formation of dust storms, prevails. The combination of high erosion wind potential with low precipitation, low relative air humidity, contributing to the desiccation of upper soil horizon, its poor resistance to deflation, surface insecurity before the beginning of the growing season creates a high deflationary danger of spring period, with sheer number of dust storms and rare hurricanes.

The eroding ability of wind is determined by the deflationary wind potential $\left(r_{j}\right)$. As exemplified by the Preolkhon region, the climatic index of deflation (C) was equal to 18 . Nine dust storms were observed here. Accumulation on the experimental sites on the slope was $355 \mathrm{~g} / \mathrm{m}^{2}$. In 2003 the climatic index was 13, four dust storms were registered and accumulation module was $89 \mathrm{~g} / \mathrm{m}^{2}$, in 2008 these values were equal to 71 and 76 . Maximum wind loads are observed on the western coast of Baikal, where the fast moving air currents experience lateral constraint in the mouths of Sarma, Goloustnaya and other river valleys. The annual deflationary wind potential is more than 100 here. In Western Transbaikalia its value varies from 30 to 60 , and in southeastern Transbaikalia even more than up to 80 . 
On the coast of Baikal in the delta of the Goloustnaya River the number of days per year with strong wind averages 52 , with an average annual wind speed of $5.6 \mathrm{~m} / \mathrm{s}$. According to our calculations, wind loads $\left(r_{j}\right)$ in the Baikal'skaya depression during the period of research varied from 112 (2005) to 138 (2007). The winds of the NW, NNW and N directions, caused by the breakthrough of cold air masses through the narrow valleys of the Primorskii Ridge, are distinguished by special force. The winds are characterized by exceptional gustiness. They always blow across the lake and, compared to other Baikal winds, have the longest duration-from August to December. The wind can reach a particularly large force $(40 \mathrm{~m} / \mathrm{s})$ in the area of the Sarma River and in the valley of the Goloustnaya River. According to T.T. Taisaev, under their influence dry stony steppes with a hollow-ridge relief, with depressions, sulphate lakes appeared along the western coast of Baikal [11]. A detailed analysis of the wind regime, performed for the points in the south of Transbaikalia, revealed the spatial and temporal features of changes in the deflation potential of the wind [12]. The greatest deflationary danger is represented by the wind loads in spring, which bring this territory closer to such areas of intensive development of aeolian processes as the Caspian depression and the plains of Central Asia [13].

\subsection{Spatial and Temporal Regularity of Processes}

There are 3 regions of intensive development of aeolian processes in Transbaikalia: Baikal'skii, Selenginskii, and Daurskii. According to the peculiarities of aeolian migration, they closely interact with each other and with neighboring systems and form a single regional aeolian system. Their migration vector is directed from the northwest to the south and southeast (see Figure 1). The manuscript considers every link in this system.

\subsubsection{The Baikal'skii Region}

The Baikal region is characterized by the maximum intensity of the processes, among other aeolian subsystems due to the extremely high deflationary wind potential. It includes the hollow of the Middle Baikal, its eastern and western coast. Here, the valleys of the Sarma, Anga, Bugul'deika, Goloustnaya, and other rivers, going down the hill, cut through the Primorskii Ridge and form natural "wind tunnels" (Figure 2a,b). The wind speed increases significantly, often having the hurricane force of $30-50 \mathrm{~m} / \mathrm{s}$. Long and powerful deflation in the Olkhon region manifest itself in the vivid morphological "ruin relief" of the slopes [14] and in the formation of blind creeks. In the Tazheranskaya steppe, wind niches and blowing rock rills on the walls of the rocky outcrops are fairly common. Deflation basins can be often found in the central parts of the rocky ruins [15].

The main forms of the aeolian relief here are deflation basins and dunes. Dunes reach a height of $5-10 \mathrm{~m}$, and the depth of blow-out depressions is $5-15 \mathrm{~m}$. Near the village of Khuzhir along the Baikal coast, two dune fields $1.5-2.5 \mathrm{~m}$ high, completed by the consertal quartzo-feldspathic sands with the fineness modulus of 2.3-3.1, were observed. The drift dune fields caused a street transfer, constructed in 1950, because of the forest cutting on that place. The sand transfer followed deforestation and terrain disturbance and reached the speed of about $10 \mathrm{~m}$ /year. Coming up to the forest limit, the sand moving slowed down to $2-15 \mathrm{~cm} /$ year.

Deflation surfaces are widespread in the mouths of valleys, which are covered by deflationary debris of different genesis and size (see Figure 2d). Accumulative aeolian forms on the west coast are local. They are found in the Peschanka stow, where they are represented by numerous dunes weakly fixed by pines, and dune fields are formed near the barriers [16]. Under the influence of hurricane winds along the western coast of Baikal, dry stony steppes with a hollow-ridge relief, deflation hollows, sulphate lakes appeared [11]. The decrease in the water level in Baikal in 2004-2017 and the drainage of the coastal strip contributed to the intensification of aeolian processes within the coastal zone. Tens of thousands of cubic meters of sand were drawn into the movement during these years. 


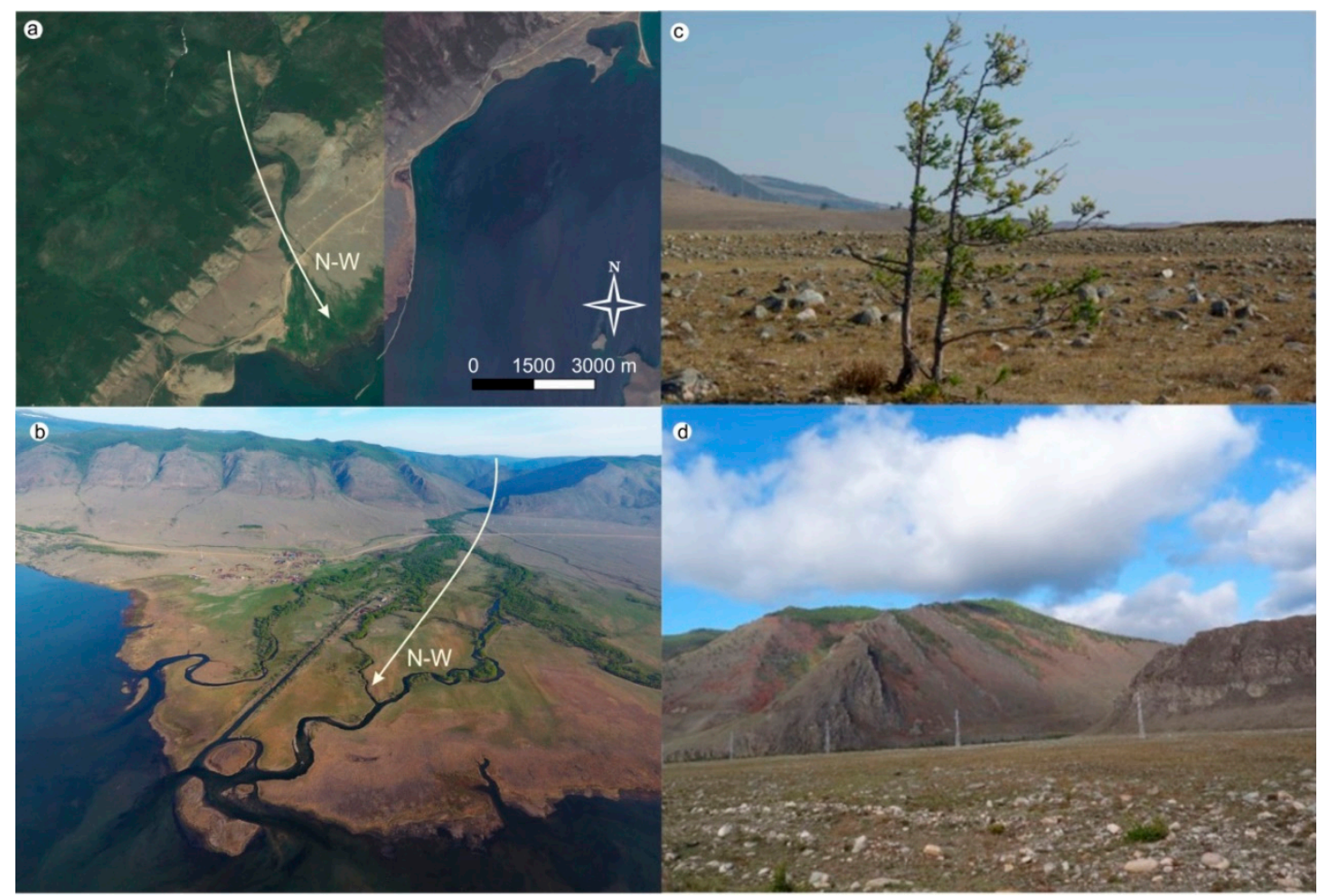

Figure 2. Deflation in the Sarma river delta: (a) — satellite image of the Sarma delta and the prevailing wind direction (electronic resource www.bing.com/maps\#), (b)-aerial photograph of the Sarma delta, (c,d)-deflation surface.

On the west coast of the Ol'khon Island, the number of aeolian forms increases. The deflation areas on the island are confined to coves and bays; they are often a continuation of the wind tunnels of the mouths of the valleys cutting through the Primorskii Ridge. Especially powerful foci of deflation are represented in the bays of the Saraiskii and Nyurganskaya Guba, "their contours are similar to the outline of the flame of giant bonfires", the tongues of which are directed into the interior of the island ([17] p. 344). They are clearly seen on satellite and aerial photographs (see Figure 3). The aeolian material is a moving matter, partly accumulating on the east coast of $\mathrm{Ol}^{\prime} \mathrm{khon}$. The thinnest particles are transferred to the Baikal water area $[18,19]$. The blowing of sandy strata and the formation of moving aeolian forms are also characteristic for the coastal part of the east coast of Baikal where blowing basins, deflation residues, dunes and sandy covers come out [20,21]. Aeolian relief forms are also widespread in the delta of the Selenga River (see Figures 3 and 4). Both ancient and actively developing forms of aeolian relief are common. Thus, although the basin of Lake Baikal is surrounded by mountain ridges, it is not an obstacle to aeolian migration of matter; moreover, it enhances it, acting as a powerful accelerator of wind flow energy. 


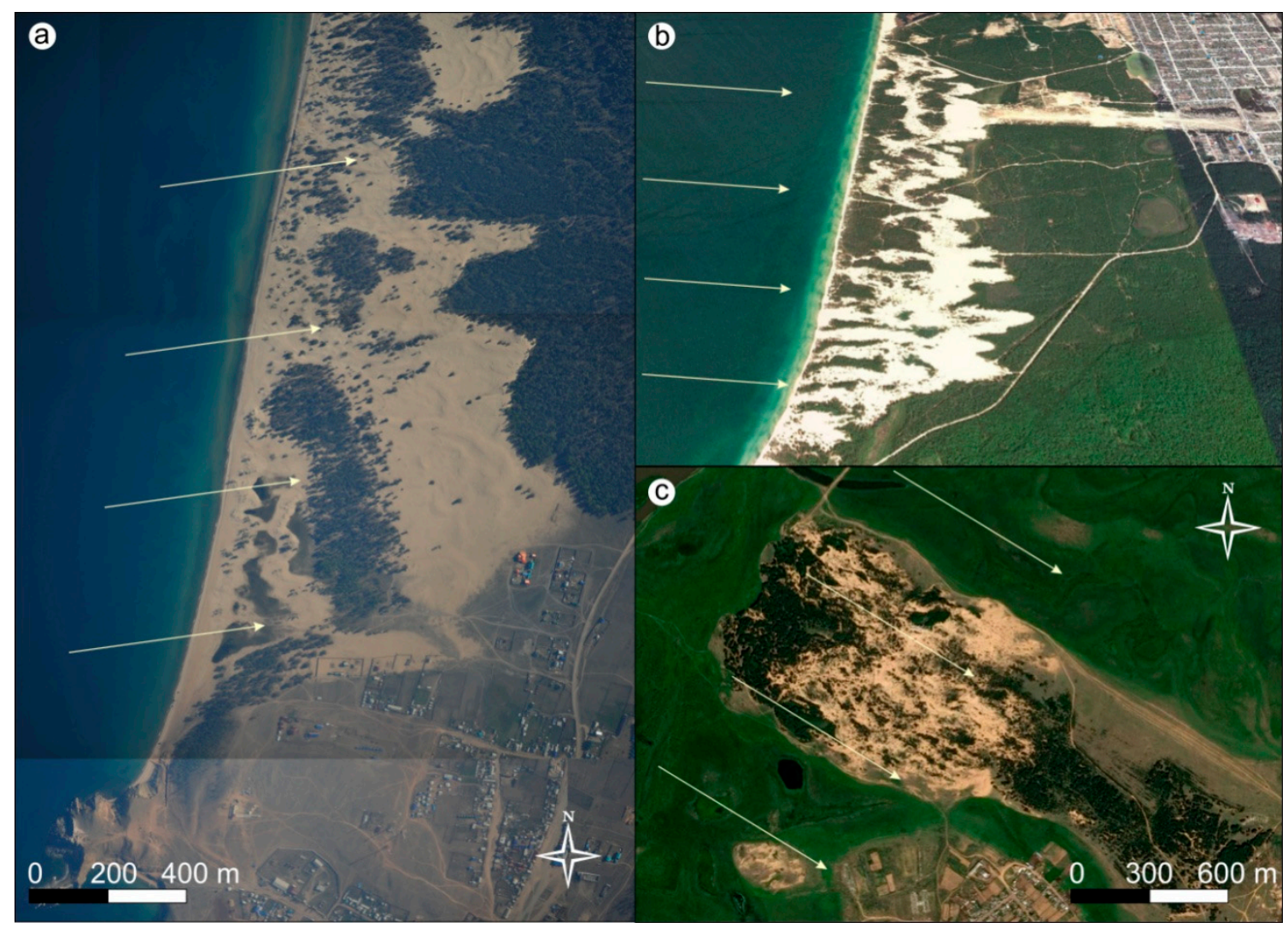

Figure 3. Drift sands of the Baikal region: (a) -western coast of Ol'khon Island (photo by the Cosmonaut Training Center, 2014); (b) -near the mouth of the Barguzin river (electronic resource www.bing.com/maps\#); (c)—the Selenga river delta (Baranii cape, 2018).

\subsubsection{The Selenginskii Region}

The Selenginskii region occupies the southwestern Transbaikalia (the Selenga River basin) within the Selenginskoe middle mountains. When leaving the Baikal basin, the wind flows "spread out" into separate streams in accordance with relief features. The peculiarity of the territory was emphasized by V.A. Obruchev: the areas of waving (deflation) and aeolian accumulation are alternately located here following each other [22]. The orographic pattern creates conditions for the emergence of air corridors defining the directions of the main winds. The relief is characterized by mountain ridges, stretched in a sub-latitudinal direction and separated by extensive intermountain hollows. The area is characterized by the wide spreading thick sandy sediments. Progressive development of deflation processes causes the formation of mobile sands foci here (Figure 4). Their area in the 19th-20th centuries varied from 1 thousand hectares in 1895, 17 thousand-in 1934, and finally up to 100 thousand hectares in 1964 [2]. According to the survey data, the first foci of mobile sands appeared somewhere in the years 1840-1855 [2], their formation began after the deforestation during the years of extremely low moisture.

V.A. Obruchev paid special attention to this problem [1] pointing to the need for urgent measures to fix the sand. He emphasized that construction of railways, increase in population, transition of local population to a settled way of life, all this contributed to the intensified deforestation, plowing up new lands and laying of wheel roads. As a result, "the bare sandy area [ ... ] expands like an ulcer" ([1] p. 54). 

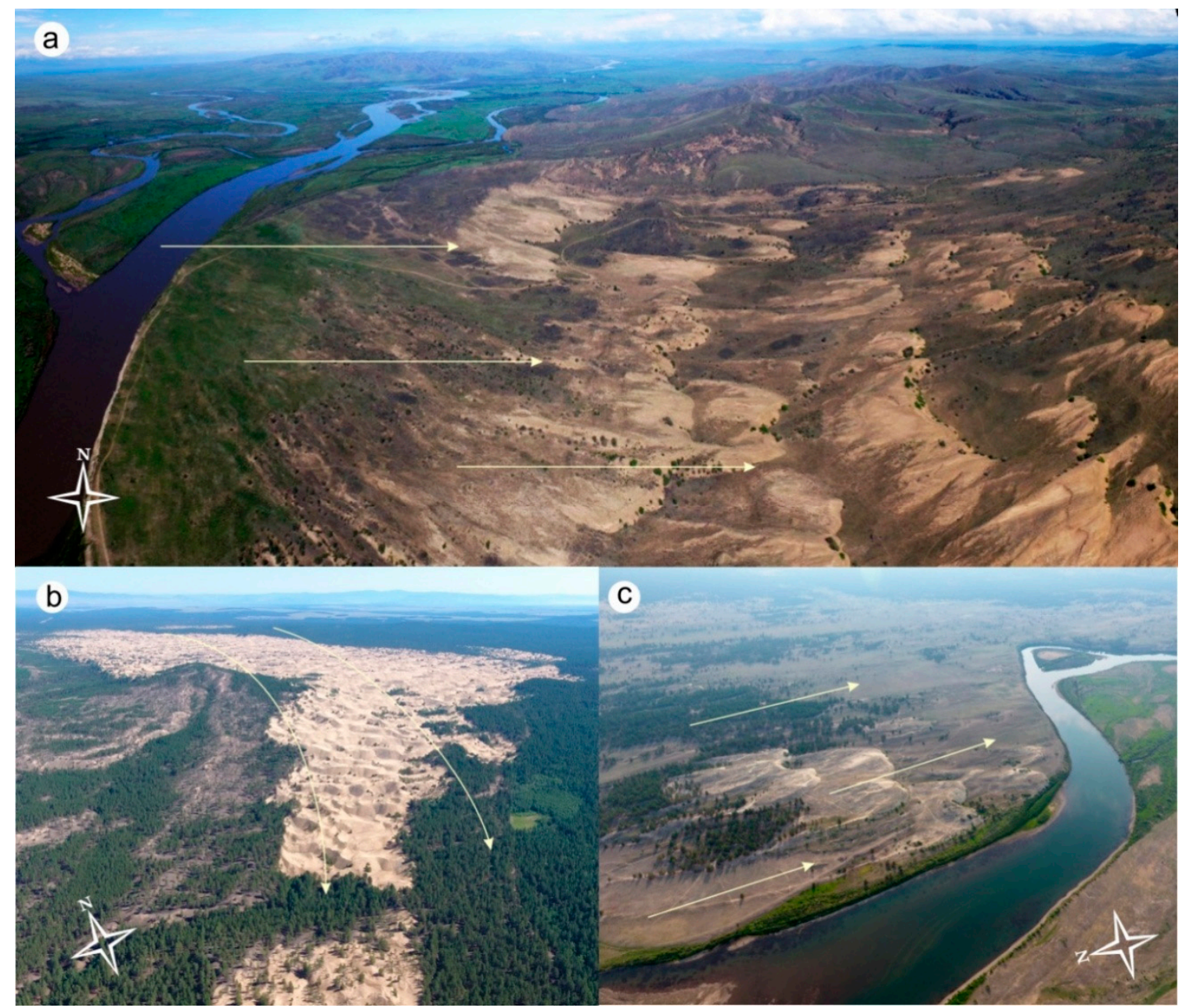

Figure 4. Drift aeolian sands of the Selenginskii middle mountains: (a)-Nomokhonovo stow (photo by S. Makarov, 2018); (b)—Mankhan-Elysu sandy massif (2017); (c)—dunes at the mouth of the Chikoi river (2017) (arrows indicate the direction of the main air flow).

After the deforestation in the Selenga basin, catastrophic manifestations of wind erosion in low erosion resistance began. As a result of the development of new lands at the turn of the 19th and 20th centuries, in areas of very low atmospheric moisture, large areas of loose sand were set in motion. The sands brought great harm to the local population, as they drifted everywhere on the croplands and settlements. Sometimes the local people even had to be moved to another place. As a result of such changes, around 1870, the village of Preobrazhenskoe was abandoned. The area of moving sand around the village was $6-8$ versts $(1$ verst $=1.067 \mathrm{~km})$ in length and $5-6$ versts in width, and the thickness of sand in some places was an arshin $(1$ arshin $=142.24 \mathrm{~cm})$, in some places 2 arshins or more, and where there was a fence, sand mounds with a height of 2-3 sagenes ( 1 sagene $=2.1336 \mathrm{~m}$ ) appeared [23]. Seedlings of grain crops often died as were filled with sand. A further expansion of croplands, especially during the collectivization and Virgin Lands Campaign, led to an increase in soil degradation processes. Intensive deflation is currently continuing on abandoned croplands (see Figure 5). 

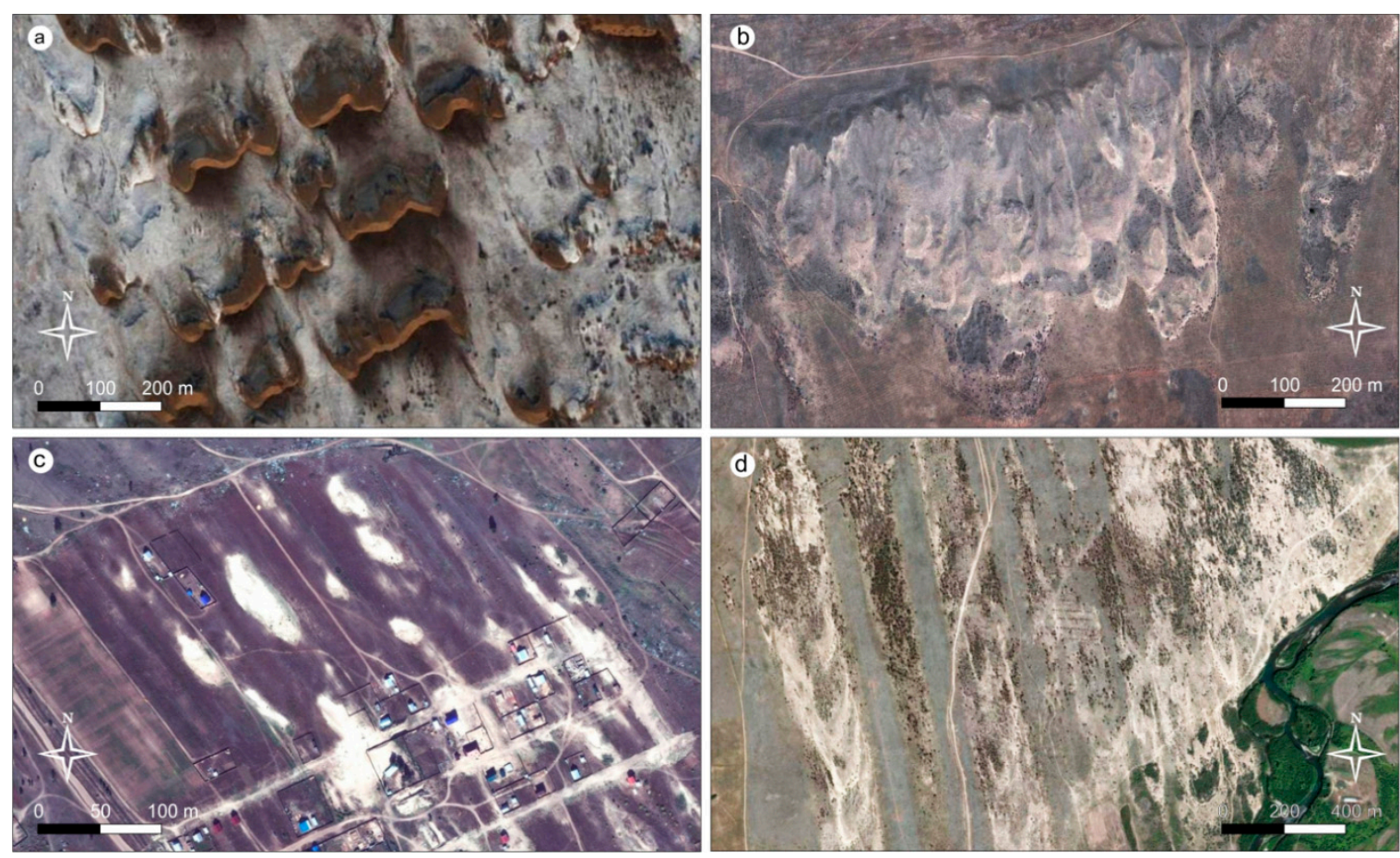

Figure 5. Deflation on abandoned croplands of the Selenginskii District: (a)-dunes at the place of abandoned croplands in the 1950s (winter photo); (b)—deflated surface of the Jida river; (c)—areas of sand fluttered in the suburb of Ulan-Ude; (d) - fields destroyed by wind erosion in the Kyakhta District.

The area has developed classical aeolian relief forms, represented by dunes, nebkhas, and numerous deflation basins. At present, both positive accumulative and negative forms show signs of deflation (see Figure 6).

Sands from the river valleys are blown by the wind to the surrounding ridges of the Selenga middle mountains. Powerful aeolian sands are widespread on the windward slopes of the Khudunskii, Zaganskii, Bugutuiskii, Kalinovyi, Tsagan-Daban Ridges, and spurs of the Borgoiskii, Dzhidinskii, Malkhanskii and other ridges [24]. Complex aeolian relief forms are observed in the area where deflation and accumulation processes are actively manifested. Thus, complex of seven dunes can be traced in the Nomokhonovo stow. The highest of them rise along the slopes of spurs of the Borgoiskii Ridge up to the watersheds (see Figure 6a) the rest are located on the terraces of the Selenga. Dunes have a different shape. The most frequent have classic shape with a height of 10-12 $\mathrm{m}$ and a width of $70-80 \mathrm{~m}$ with typical slope asymmetry, windward of $10-110^{\circ}$ and leeward of $30-31^{\circ}$ [25].

The forward movement of sands occurs mainly in the southeastern direction, the aeolian relief forms move to the south along the valleys of the Selenga, Chikoi, and Khilok rivers. In general, the Selenga link is an area of transit and partial accumulation of aeolian matter. The forest-steppe territory of Eastern Transbaikalia is also involved in aeolian migration. Aeolian facies take part in the structure of sandy strata in the Ingodino-Chitinskaya depression [26]. Further in the south, in steppes, deflation increases again. 


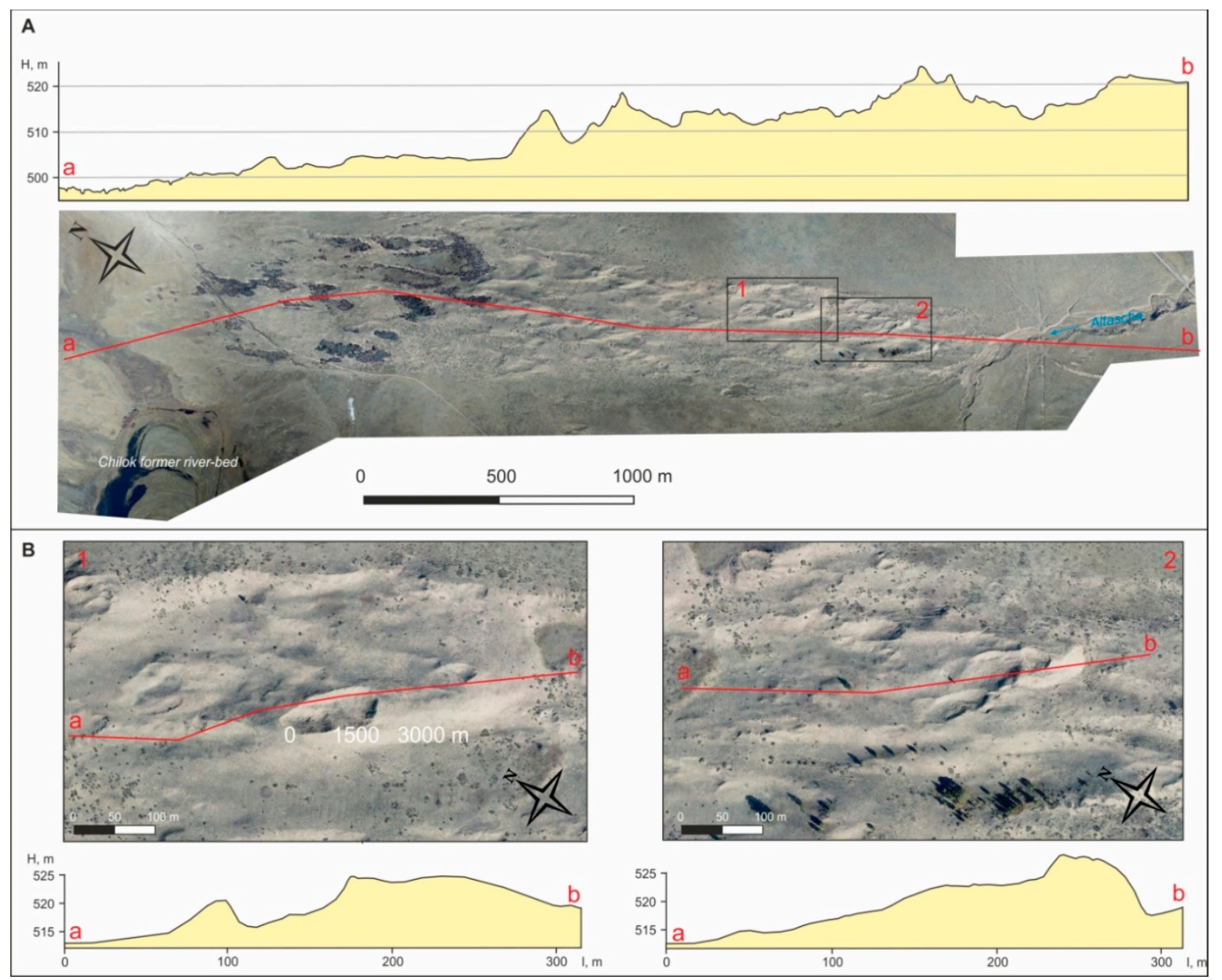

Figure 6. Aeolian relief in the mouth of the valley of the Altasha river (the Khilok valley, Selenga middle mountains). Orthophotomaps and hypsometric profiles: (A)—of the main aeolian massif, (B) - of separate dunes.

\subsubsection{The Daurskii Region}

In the South-Eastern Transbaikalia, deflation is assigned to the Daurian aeolian corridor-a vast East-Transbaikalian depression that separates the Daurskoe and Shilkinsko-Argunskoe uplifts. Geomorphologically, the territory is represented by the Priononskaya and Onon-Toreiskaya plains (see Figure 1).

There are also areas of small hills, hilly-undulating relief and inselbergs. Along the axis of the aeolian corridor from the northwest to the southeast, and in accordance with the prevailing direction of wind currents, a regular change in the morphological complexes of the land cover with aeolian activity occurs. Its peculiar zonality is noted. To the north of the latitudinal segment of the Onon river valley within the limits of the Priononskaya sandy plain, the evidences of aeolian activity are clearly visible on modern satellite images showing that salt-bearing deposits of lake basins are transported in the southeast direction (see Figure 7a). In this case, the contours of lake sediments become drop-shaped. Wind gradually fills all irregularities of the steppe relief with fine sands.

Wind activity is not limited only by deflation and aeolically filled holes. The entire plain is an active transit zone of aeolian material. For instance, in the spring of 1978, the mass of salt-bearing sediments from the Lake Nozhii bottom in the Aginskaya steppe were moved by the wind along a surface of $28.5 \mathrm{~km}^{2}$ in the southern and southeastern direction to a considerable distance, and there was a salinization of the soil surface of cropland [27]. When crossing the valley of the Onon River the aeolian lithodynamic streams "unload" on the right bank of the river and created here dunes with a height of $3-5 \mathrm{~m}$. 
Further south from Onon to the basin of the Torei Lakes, ancient aeolian relief forms are widely distributed onto the surface of the lake-alluvial plain (see Figure 7c). The most well-preserved dune fields are located on the surface of the $80-\mathrm{m}$ high accumulative terrace of the Onon river. Their height varies from 8 to $15 \mathrm{~m}$ and their length from 50-70 to 200-300 m. The dune fields are accompanied by deflation basins, the length of which does not exceed 70-100 m, and sometimes reaches a depth of 5-10 m. Long axes of aeolian relief are oriented from northwest to southeast. Some of them are now moving (see Figure 7f).

To the south of this terrace, all large lake basins, forming the lake belt, stretched parallel to the latitudinal segment of the Onon river. They divided the Onon-Toreiskaya plain approximately in half, and are subjected to wind deposition. At the same time, the aeolian hillocks and the deflation basins embedded in them have been formed along the northern coasts of the lakes which can also be clearly seen in satellite images (see Figure 7b). The sandy aeolian mounds are strongly dispersed and are currently represented only by the margin parts as separate fragments (see Figure 7e). Often, the deflation basins, connecting with each other, form a fancy maze. In the section of sandy sediments, composing the remaining parts of the aeolian mounds, 10 or more horizons of buried soils with a thickness of 5 to $30 \mathrm{~cm}$ are observed everywhere. The cultural layers of the archaeological monuments of the Late Bronze Age-Early Iron Age are assigned to the lower layers of the buried soils [28]. At the bottom of the deflation basins, there are remains of vegetation in the form of decayed trunks and rhizomes of shrubs up to $10 \mathrm{~cm}$ in diameter. All negative forms of land cover, observed on the surface of the plain, are shielded by horizons of impermeable dense lake clays.
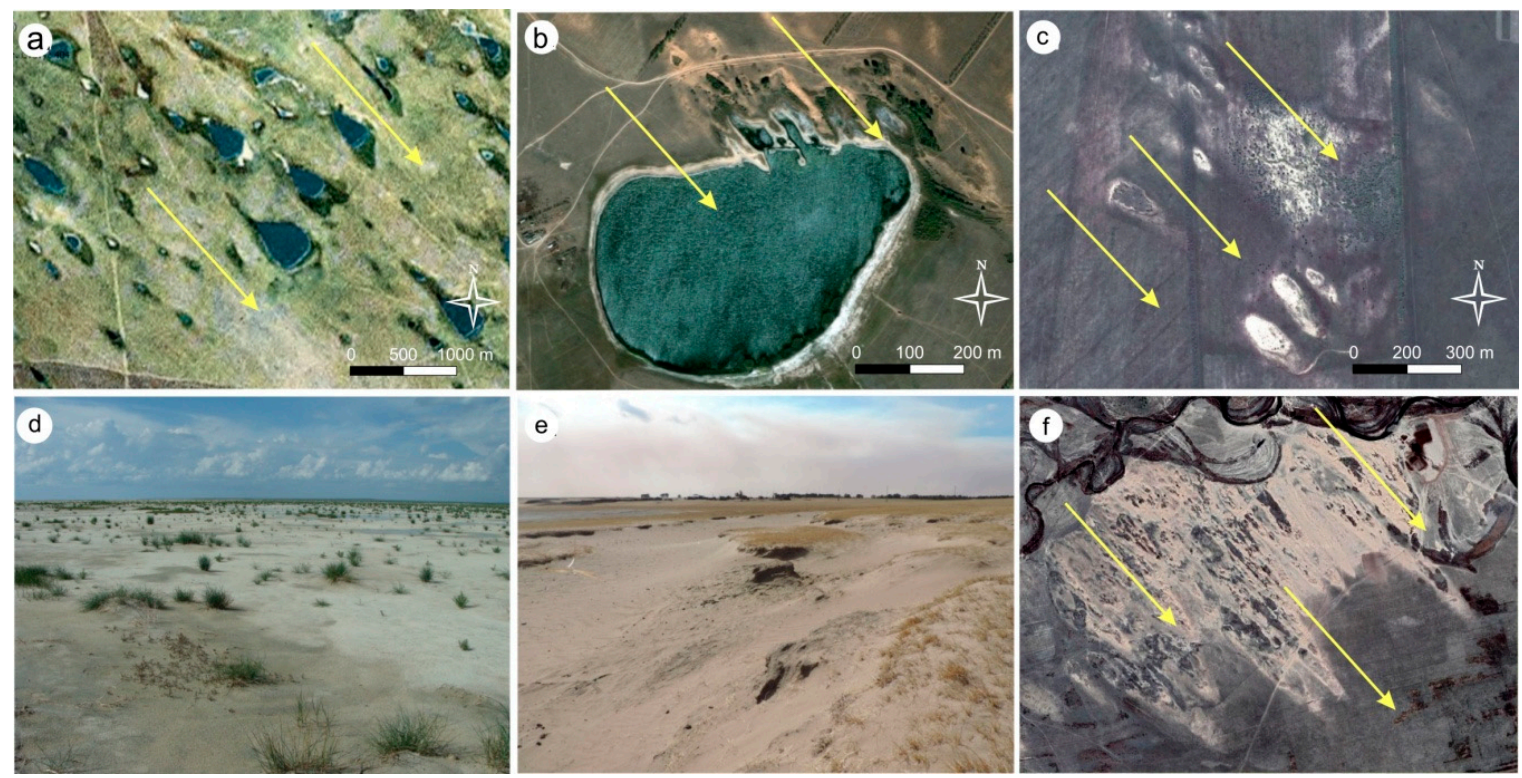

Figure 7. Morphologically pronounced traces of deflation and aeolian accumulation in Dauria: (a) - aeolian transfer of sediments of salt lakes in the Aginskaya steppe (Priononskaya Plain); (b) - deflation on the northern coast of the lake Big Yakshi; (c) -ancient dunes on the high terrace of the Onon river (Tsasucheiskii forest); (d)—aeolian processes of the bottom of the lake Barun-Torei in the dry period (July 2013); (e)—deflation basins on the northern coast of the lake Big Yakshi (spring 2014); (f)—drift sands in the south of the Onon river (the village of Chindant).

To the south of the lake belt on accumulative lacustrine and alluvial terraces, deflation basins are also widespread. They are especially well manifested in the valley of the Imalki river, in the creek valley Narin-Kundui (see Figure 7e) on the high lake terraces. The orientation of their long axes also coincides with the direction of the NW winds prevailing in Dauria (see Figure 7c). Within the lake basins, modern accumulative aeolian relief forms are formed on drained parts of the littoral in dry years (Figure 7d). Such forms are often found on the surface of deltas, deluvial, and proluvial loops. 
Moving away from the center of the corridor to the periphery, deflation prevails in areas of denudation relief. Traces of the deflationary work of the wind are clearly visible in the relief of the western bench of the Zun-Torei volcanic plateau, the Adun-Chelon and Tsagan-Olui massifs. The traces of modern aeolian activity are most vivid in the morphology of the relief are in numerous lake basins.

\subsection{Intensity of Aeolian Migration of Matter}

A generalization of the materials of long-term field observations of aeolian processes allows us to have an idea of the intensity of aeolian migration of matter in Transbaikalia. The most intense focal deflation occurs in the Peschanka stow on the western coast of Baikal. Here, on the numerous dunes, weakly fixed by pine, intensive sand blowing is a process leveling surface at an average annual speed of 2.4 to $34.1 \mathrm{~mm}[16,17]$. The deflation capacity from under the roots of the pines reaches $2.5 \mathrm{~m}$. Experimental observations of aeolian processes have been carried out since 2006 on the site of the southern macroslope of the Primorskii Ridge, facing the delta plain of the Goloustnaya River. Here, wind denudation has an aerial character and the delta plain of the Goloustnaya River is the deflationary surface at the regional level. When a loose cover is disturbed, the fine particles are quickly swept away by the wind and re-spreads over the surface of the plain. The actual volume of loose material carried out correlates with the frequency of dust storms. The average deflation rate at the Goloustinskii experimental field varies in accordance with the structure of climatic variations from $1 \mathrm{~mm}$ in relatively wet and cold years to $5 \mathrm{~mm}$ in warm and very dry years. High intensity of aeolian processes here is observed between the Krestovskii Cape and the mouth of the Sarma River on the Kocherikovo-Ongurenskoe plateau, in the western and north-western parts of the Ol'khon Island and in Preol'khon region.

The average rate of areal deflation in Western Transbaikalia, determined from archaeological data was $0.6 \mathrm{~cm} /$ year for 1000 years and, measured by natural reference points, was $1-8 \mathrm{~cm} /$ year [2]. On the deflated denudate sands of Krivoi Yar in the Nizhneudinskaya depression, the maximum value of deflationary denudation for the spring period is $12-15 \mathrm{~cm}$; and in the summer-autumn it decreases to $2 \mathrm{~cm}$ [29]. The intensity of linear deflation in the wind corridors of meridional valley narrowing is enormously higher. The deflation reaches its maximum activity in spring during strong winds, the relative humidity of the air often drops below $30 \%$, and the moisture ratio in dry steppes is as in deserts and semi-deserts. The maximum speed of movement of dunes reaches $16 \mathrm{~m} /$ year in the area of the Bolshaya Kudara village, the minimum $-0.22 \mathrm{~m} /$ year in the Monkhan-Elysu stow. The average speed is $6-8 \mathrm{~m} /$ year [2]. The average speed of dunes in the Nomokhonovo stow for the period from 2000 to 2013 was $1 \mathrm{~m}$ /year (see Figures 8 and 9).

In the southeastern Transbaikalia in the spurs of the Nerchinskii Ridge, weak deflation is observed on gentle windward slopes. Its value is $0.01-0.05 \mathrm{~mm}$ per year; moderate deflation at a rate of 0.1-1.5 mm per year is typical for the middle part slopes, ablation from the upper steeper sections of the slopes increases to $2.2-2.6 \mathrm{~mm}$ per year [8]. The volume of the aeolian material carried out from the apical surfaces can make a denudation layer of $3-5 \mathrm{~mm}$, reaching sometimes $10 \mathrm{~mm}$ per year [9]. The largest amount of aeolian deposits in dust collectors accumulated in the bottom of the pad' and in the lower accumulative part of the slopes of the southern exposure; the aeolian accumulation varied from 0.3 to $2.0 \mathrm{~mm}$ /year from 1964 to 1980 . Observations, using benchmarks, showed that in the dry phase of 2008-2012 aeolian accumulation of matter prevailed on the steppe slopes, the average value was $0.72 \mathrm{~mm} /$ year [7].

In general, the intensity of the processes varies from the center of the corridor (dry bottoms of lake basins) to the periphery (spurs of ridges) several thousand times. At the same time, the average deflation rates on the steppe slopes are hundredths or tenths of a millimeter per year, and the drift from the summit surfaces with sparse grass stand increases up to the first millimeters. The average aeolian accumulation rates vary from 0.18 to $3.0 \mathrm{~mm}$ /year, and the maximum in negative landforms (in ravines and lake basins) sometimes reach $0.7-1.5 \mathrm{~m}$ in $2-3$ years. Summing up on a geological time scale, such rates of aeolian processes cause a noticeable relief restructuring. 


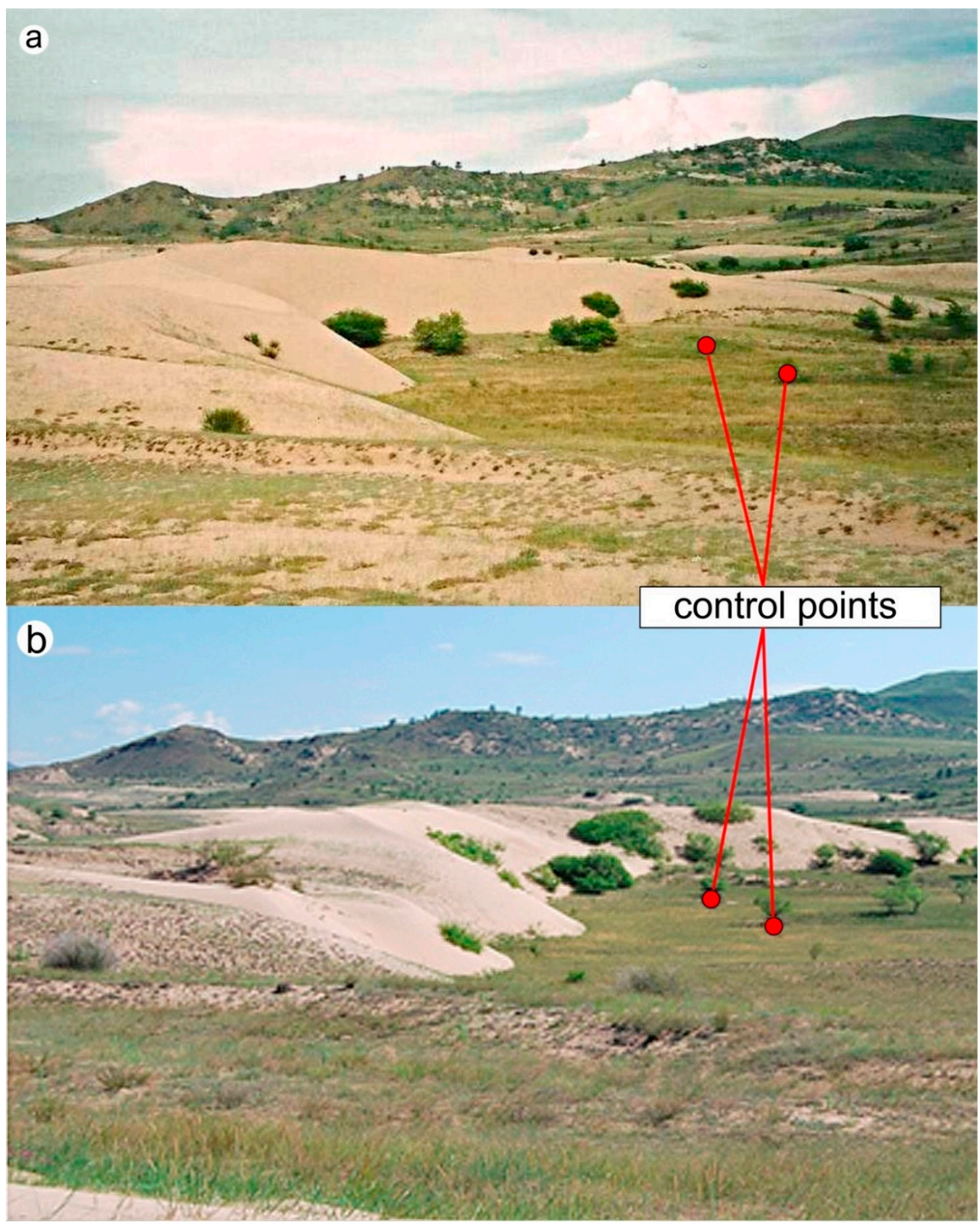

Figure 8. Dynamics of dune field chain in the Nomokhonovo stow in the valley of the Selenga river for the period from 2000 (a-photo by T. Shchipek) to 2013 (b-photo by D. Kobylkin).

It is estimated in the experimental research using predictive quantitative models of wind erosion in the south of Transbaikalia that five types of landscapes with different intensity of deflation can be distinguished [12]. The first type includes the taiga landscapes, where deflation is practically absent, and aeolian accumulation has a background planetary character and is extremely insignificant. The second type unites forest-steppe landscapes with low deflation, and aeolian accumulation prevails here. Landscapes of true steppes belong to the third type, in which the intensity of wind erosion varies from moderate to strong, and the value of the average perennial soil loss from deflation is $1-10 \mathrm{t} / \mathrm{ha}$. This type includes steppes in intermountain hollows. The fourth type of landscape with a 
high intensity of deflation (up to $50 \mathrm{t}$ /ha per year) is characteristic of dry steppes of the Selenga middle mountains and Daurian steppes. Finally, landscapes with extremely high values of deflation, transfer and accumulation of aeolian matter are united into the fifth type (the module of aeolian migration of matter reaches $100 \mathrm{t}$ /ha per year or more). The fifth type includes anthropogenically disturbed areas of waving sands on the shores of Baikal, in the valleys of the Selenga and Onon rivers, as well as in lake hollows.

\subsection{Long-Term Variability of Aeolian Migration of Matter}

The development of aeolian processes having a pulsating character in time over the past 500 years was uneven and subjected to the general moisture regime of the northern hemisphere [7,12]. Periods of increased intensity of wind erosion were followed by periods of attenuation of deflation and reduction of environmental impact. Extreme deflation was characterized by the Maunder period (1620-1700), which was characterized by a rather sharply beginning cold period, accompanied by a significant decrease in moistening. This period represented a landmark in the development of aeolian processes in East and Central Asia, "after it, the increase in the duration of deflation periods is quite clearly established as an indicator of the steady trend of general drying of the region's territory in the last three centuries of the second millennium" ([13] p. 154).

In the Holocene, the aeolian processes in the steppes of Dauria were also evolving unevenly and obeyed the regime of variation in humidification of the territory. In neighboring areas of Mongolia, deflation reached a maximum at the Boreal and Subboreal periods of the Holocene [30]. For studying the dynamics of the aeolian processes during the Holocene, we investigated the sediments in the Krementui pad' (see Figure 9). The pad' represents a trap catching some of aeolian material that is removed by deflation from the basin of the Torei lakes, and from the upper layers of the relief of the western, more elevated, portion of the pad' basin along the north-westward direction and accumulates in topographic depressions over a long period of time. The fullest structure of aeolian deposits along the right side of the pad' in the zone of wind shadow on the slopes and in small saddles. In one of the saddles, section No. $4290 \mathrm{~cm}$ in depth was established (see Figure 5). The section is characterized by a monotonic structure, with a gradual increase in weight of the mechanical composition of the deposits from top to bottom, from heavy sandy loam to light loam as well as by a total absence of inclusions in the form of coarse fragments. The section clearly shows several buried humus horizons, giving evidence of interruptions in aeolian accumulation of material. The lower soil layer at a depth of $245-250 \mathrm{~cm}$ contains $1.15 \%$ of organic carbon, and its age is $8050 \pm 150 \mathrm{cal}$. ya (LU-7452). In the second humus horizon aged $6440 \pm 160 \mathrm{cal}$. ya (LU7451), at a depth of 183-188 cm the content of organic matter decreases to $0.49 \%$. The buried soil horizon at a depth of 95-100 cm contains also a small amount of organic carbon $(0.58 \%)$, and its age is $4650 \pm 130$ cal. ya (LU-7450). Initially (during the formation of the lower and middle bedsets of deposits), aeolian accumulation was proceeding at the rate of 0.41-0.42 mm/year; after that, its rate decreased nearly twice: the upper bedset of deposits to a depth of $95 \mathrm{~cm}$ was forming at the rate of $0.23 \mathrm{~mm} /$ year. The lower, darkest and thickest soil that had formed at the beginning of the Atlantic period is of widespread occurrence on the Onon-Toreiskaya plain [28], and in neighboring areas of Mongolia [13,30]. In the bottom of the pad', the formation of aeolian-deluvial deposits, according to data from section No. 6, began after the end of the fluvial dynamical phase of morphogenesis, approximately 5280 years ago [31]. The mean rate of their accumulation was $0.18 \mathrm{~mm} /$ year. The upper half of the layer comprising whitish/grey heavy loam about $45-50 \mathrm{~cm}$ in thickness has an aeolian origin. These deposits began to accumulate after the formation of the upper buried soil whose age is $2910 \pm 320$ cal. ya (LU-7457). According to data for neighboring areas of Mongolia, it is about 3000-3400 years ago that the drying of the territory increased substantially: the overflow and the size of Lake Buir were decreasing, the soil cover began to be dominated by chestnut soils, with the steppe and dry steppe predominating in landscapes [30]. Under these circumstances there occurs a dramatic enhancement in the aeolian processes which played a dominant role in the formation of the upper layer of deposits. The period of increasing intensity in aeolian processes is also 
correlated with the accumulation period of aeolian deposits within the floodplains of the Aga and Ilya rivers about 3000-2000 years ago [32]. A progressive drying of the territory continued during a subsequent period as well. The tendency for an enhancement in aridization of Eastern Transbaikalia for the last 1900 years is recorded based on a study into layer-by-layer palynological spectra and chemical composition of bottom sediments from Lake Arakhlei [33]. Thus, the pulsating nature in the intensity of aeolian processes over time due to climatic fluctuations is typical for the Transbaikalia. A sharp increase in processes is noted periodically, when they acquire an extreme (catastrophic) character.

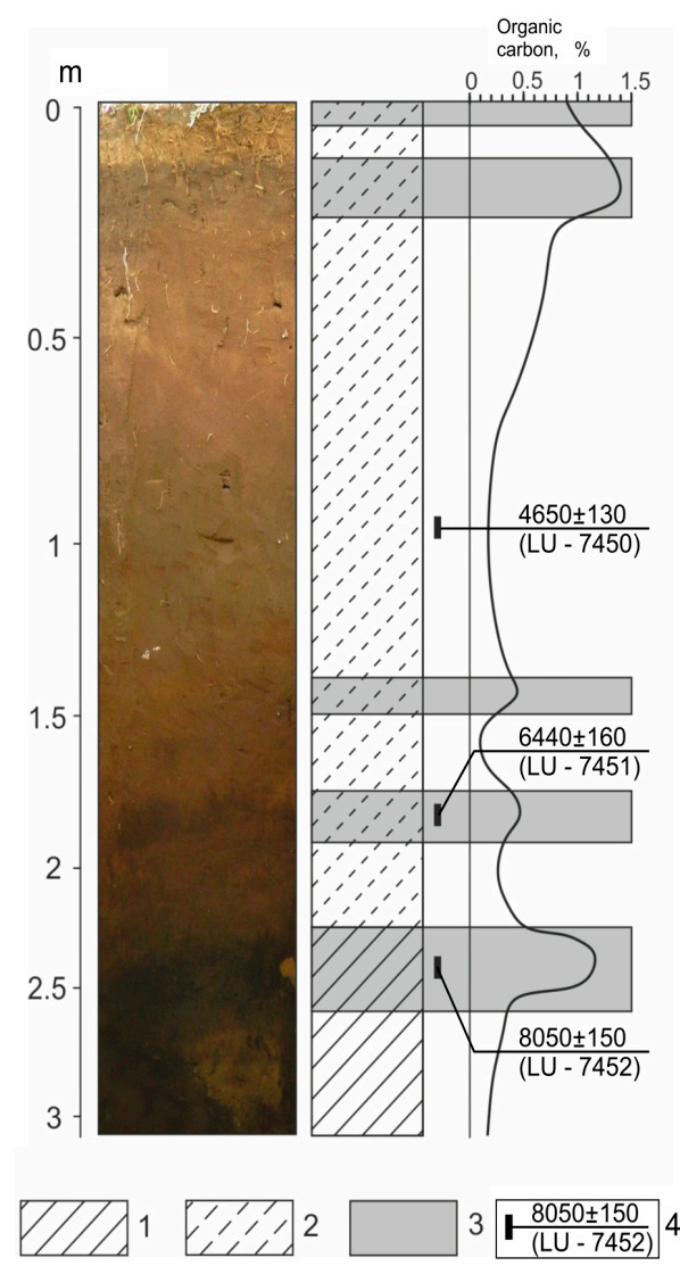

Figure 9. The structure of the Holocene aeolian deposits in the Krementui Pad' (section no. 4). Deposits: 1-light loam, 2-sandy loam, 3-humified material, 4- ${ }^{14} \mathrm{C}$ sampling.

\subsection{Extremals of Aeolian Processes}

Extremals of aeolian processes are associated with negative anomalies and extremes of precipitation. In Transbaikalia a sharp increase in aeolian activity was noted in 1902-1903, 1921-1922, and 1929, in the early 1940s, late 1960s, and early 1980s. Against the background of these fluctuations, characteristic of individual regions, there are general periods of their intensification (the beginning of the 1920s and 1980s), caused by strong droughts that extend to the whole south of Siberia.

To identify extremals we analyzed long-term series of dust storms and annual values of the complex climatic deflation indicator [34]. The dynamics of solar activity has been taken as a guideline in identifying extremals of deflation.

In Transbaikalia, the association of extreme aeolian events with the maxima of solar activity cycles has been established (see Figures 10 and 11). Moreover, extremals of dust storms are in relation to large regional droughts and maximums of the climatic deflation index by one to two years. According to the station in Ulan-Ude, a large outbreak of aeolian processes was noted in 1960 (see Figure 11). In 1970, 
1979-1981, 1992, and 2002 large areas of agricultural land and some populated areas were covered with sand. The same mechanism of the formation of extreme aeolian events is also characteristic of the Onon-Argunskaya steppe, where a series of dry years leads to a sharp increase in the climatic deflation rate and then to a catastrophic manifestation of aeolian processes. In the neighboring regions of Eastern Mongolia an 11-year cycle of repetition of the strongest hurricanes is also distinguished [13].

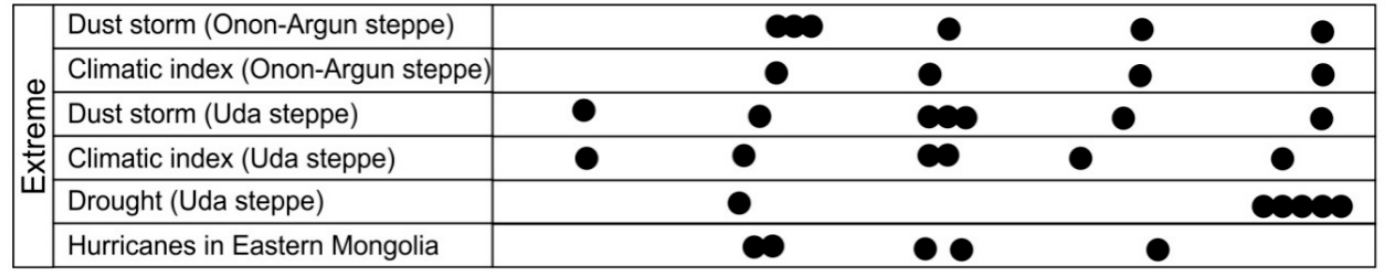

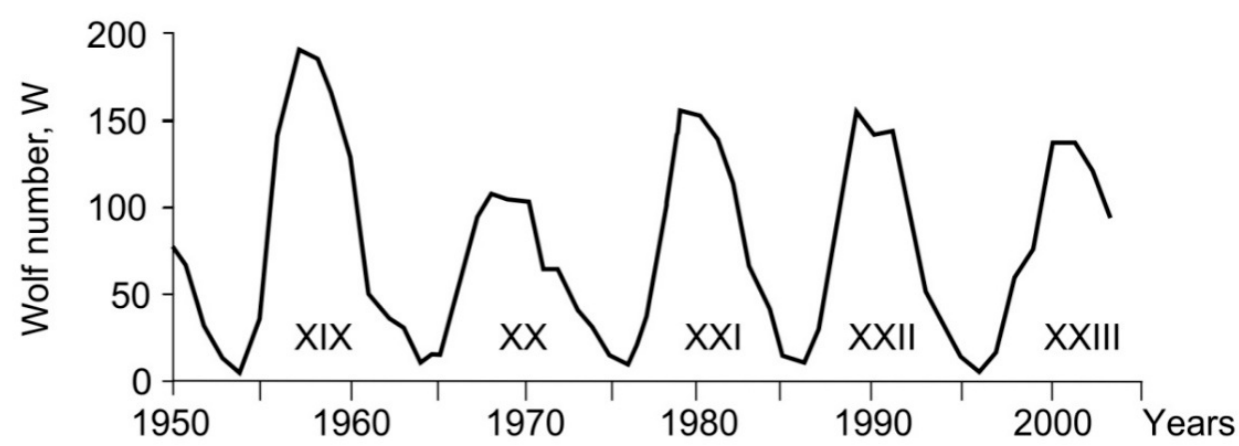

Figure 10. Location of extreme events of aeolian processes relative to solar activity cycles (XIX-XXIII). C—climatic indicator of deflation; DS—dust storms. Hurricanes (Eastern Mongolia) are given according V.P. Chichagov (1998).

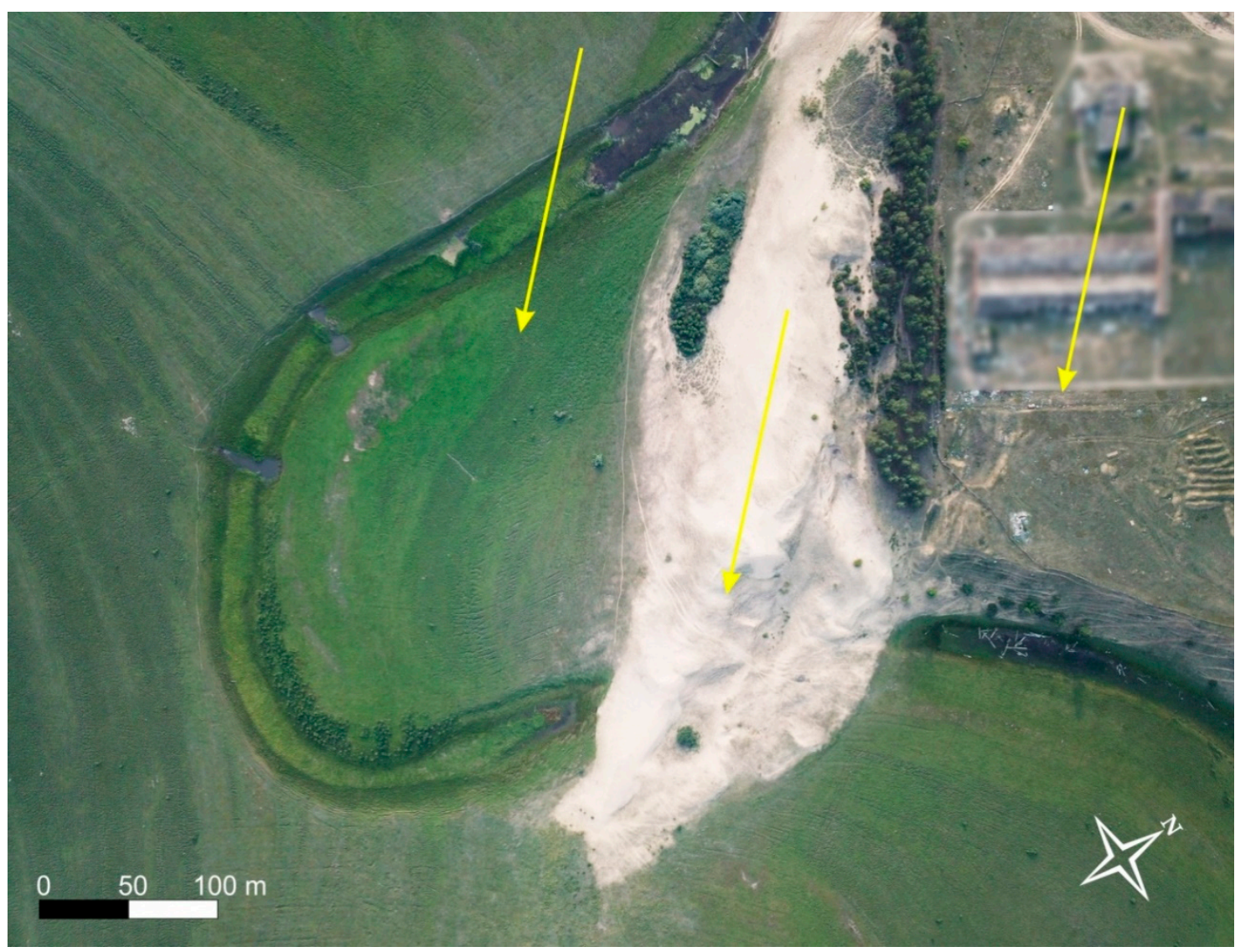

Figure 11. Dune field blocked the channel in the Selenga delta near the village of Kudara (2018). 


\subsection{Aeolian Processes and Geomorphology}

The long-term inherited development of aeolian processes in Transbaikalia has a significant effect on the relief. At the same time, almost all of both large and small landforms of this vast territory are shaped by wind streams. Depending on the combination of climatic, tectonic, orographic, lithological, and landscape conditions and factors, as a result of wind exposure, both accumulative and deflational relief forms can be created and, ultimately, both the alignment and the dismemberment of the relief can occur.

Deflationary dismemberment of the relief occurs in the Selenga middle mountains in areas of narrowing of the valleys that cross the mountain ridges (Khamar-Dabanskii, Kalinovskii, Borgoiskii, Zaganskii, and other wind corridors). Powerful aeolian sands are widespread on the windward slopes of Khudunskii, Zaganskii, Bugutuskii, Kalinovskii Ridges, Tsagan-Daban, spurs of Borgoiskii, Dzhidinskii, Malkhanskii, and other Ridges.

On denudative and denudative-accumulative plains, the predominant direction of the aeolian effect on relief consists in its alignment due to powerful deflationary denudation. The alignment mechanism is determined by the maximum aeolian drift of the matter from the upper relief elements, figuratively speaking, by "aeolian polishing" of the summits and by partial filling of erosion holes. On the wind-blown slopes of the northwestern exposure due to intense deflation, the summit ledges retreat and pediments are expanded. At the same time, the upper layers of the slope sediments undergo deep aeolian processing, where the debris congestion sharply increases, and salt-bearing sediments of the dry bottoms of lake basins are blown out.

As a result of deflationary denudation a low ridge microrelief is formed on the windward slopes, which is associated with the preparation of rocks that are more resistant to fracture. Low-thickness, loose cover on such slopes is often broken by bedrock outcrops. On the leeward slopes, a portion of the aeolian material accumulates. Aeolian redistribution of material between the slopes leads to an increase in the steepness of the windward slopes and the flattening of the leeward.

In the steppe of the southeastern Transbaikalia the upper horizons of the slope deposits are "processed" by the wind. A strong aeolian differentiation of fine particles is observed mainly on the slopes of denudation residues, where exposure differences in the content of physical clay are clearly manifested, i.e., the depletion of the north-western exposures by the clay particles and the south-east enrichment with them. Since fine particles are constantly removed from the slopes of denudation residues by deluvial processes, traces of aeolian differentiation of fine particles occur in a layer of $0-20 \mathrm{~cm}$, and below the texture are leveled.

Different directions of the aeolian processes on the slopes of the denudation residues caused their asymmetry. Steepness of slopes of northern and western exposure, dominated by aeolian denudation, reaches $14-18^{\circ}$. In some places on the slopes bedrock is exposed to the surface, which is covered with chipping. The steepness of the eastern and southern slopes, where the accumulation of aeolian material is observed is, as a rule, $3-5^{\circ}$. Below the denudation residues the slopes are also influenced by the aeolian factor, but weaker, therefore, it is almost not expressed morphologically, but is manifested in a change in the structure of the upper horizons of the slope deposits.

Fluvial and laqustrine relief complexes experience a strong effect of aeolian flows. Evidences of aeolian processes are clearly recorded in river valleys. Of particular note is the opposite direction of water and wind flows in the valleys of the Selenga river basin. If the drawn, suspended and dissolved material naturally flows downstream (from the basin) by river flows, then most of the aeolian flows here transfer fine particles in the opposite direction, i.e., to the basin. There are even cases of complete blocking of the river beds by the aeolian moving sands (see Figure 10). In the valleys of the rivers in areas located above wind corridors, where the speed of wind flows sharply decreases and aeolian accumulation is noted, the tracts of aeolian sands are recorded. The effect of aeolian processes on the morphology of the relief of the Daurian region especially increases in extremely dry arid phases of relief-formation cycles [8]. In the river valleys drained sections of the channels, low and high floodplains, the first terrace above the floodplain, sandy plains of the middle course of the Onon river 
are exposed to intense blowing. Vast deflation basins are formed in the Uldzi river valley and within the lake belt of the Transbaikalian steppes. Deflation considerably flattens the drained low shores of the Torei Lakes and carries out lake sediments from the central parts of the lake basins. Drift sands are formed in the coastal zone [7-9].

\section{Conclusions}

Our research established that as a result of the functioning of numerous deflationary and transit-accumulative aeolian subsystems, combined into a large regional morphodynamic system, a powerful removal of matter from the Transbaikalia to the south and southeast to neighboring regions of Mongolia and China is carried out. When this occurs, differentiation (sorting) of the material, located in the zone of wind exposure occurs, i.e., the coarse sediments remain in the zones of deflation, and the fine particles are transported over long distances. The morphological traces of the aeolian migration of matter in Transbaikalia are represented by a wide variety ranging from deflation outcrops and depressions to extensive tracts of loose (drift) aeolian sand. The functioning of aeolian processes affects the course of many geomorphological processes, primarily the fluvial ones. In the river valleys of the Selenga basin, aeolian and fluvial flows of matter are often directed towards each other. In arid phases of relief-formation cycles of various hierarchical levels, when atmospheric moisture decreases sharply and the area of numerous salt lakes decreases, the steppe landscapes of Transbaikalia act as an arena for intense deflation and represent a corridor through which the aeolian migration of matter occurs. The established patterns of distribution of the zones of deflation and aeolian accumulation depending on the morphometric characteristics of the relief make it possible to use the results of the study in mapping of aeolian processes, paleorestructures of changes in the natural environment and predictive assessments.

Author Contributions: O.B. and D.K. conceived of the presented idea. E.T. developed the theory and performed the computations. O.B. and E.T. verified the analytical methods. O.B. encouraged D.K. to investigate aeolian processes and supervised the findings of this work. All authors discussed the results and contributed to the final manuscript.

Funding: The work was supported by the Russian Foundation for Basic Research (17-29-05064). Integration program "Fundamental research and breakthrough technologies as a basis for advanced development of the Baikal Region and its interregional relations" (No. 0341-2017-0001).

Conflicts of Interest: The authors declare no conflict of interest.

\section{References}

1. Obruchev, V.A. Dry Sands of the Selenginskaya Dauria and the Need for their Speedy Research, Works of the Troitsk-Sava-Kyakhta Branch of the Amur Division of Imp; Russian Geographical Society: Saint Petersburg, Russia, 1914; Volume XV, pp. 53-67. (In Russian)

2. Ivanov, D. Aeolian Sands of the Western Transbaikalia and the Baikal Region; Buryat. Knizhn. Izd.: Ulan-Ude, Russia, 1960; 230p. (In Russian)

3. Sochava, V.B. Onon-Argunskaya Steppe as an Object of Stationary Physiographic Research. In Alkuchansky Govin. Field Research Experience of the Steppe Landscape; Nauka: Leningrad, Moscow, 1964; pp. 3-23. (In Russian)

4. Obruchev, V.A. On the Weathering and Deflation Processes in Central Asia. In Selected Publications on the Geography of Asia; Gos. Izd-vo Geogr. Lit.: Moscow, Russia, 1951; Volume 3, pp. 131-160. (In Russian)

5. Goudie, A.S. Arid and Semi-Arid Geomorphology; Cambridge University Press: New York, NY, USA, 2013; 454p.

6. Chepil, W.S.; Siddoway, F.N.; Armbrust, D.V. Climatic index of wind erosion conditions in the Great Plains. Proc. Soil Sci. Soc. Am. 1963, 27, 449-452. [CrossRef]

7. Bazhenova, O.; Tyumentseva, E. Contemporary Aeolian Morphogenesis in Semiarid Landscapes of the Intermountain Depressions of Southern Siberia. Catena 2015, 134, 50-58. [CrossRef]

8. Bazhenova, O.I.; Kobylkin, D.V.; Makarov, S.A.; Rogaleva, N.N.; Silaev, A.V.; Cherkashina, A.A. Reconstructing the Aeolian Processes in Daurian Steppes During Arid Phases of Morphogenesis. Geogr. Nat. Resour. 2015, 36, 289-299. [CrossRef] 
9. Bazhenova, O.I. Daurskii Aeolian Corridor. In XXXVI Plenum of the Geomorphological Commission of the Russian Academy of Sciences: Materials of the All-Russian Scientific-Practical Conference with International Participation "Geomorphology_The Science of the 21st Century; Publishing House Alt. Univ.: Barnaul, Russia, 2018; pp. 32-38. (In Russian)

10. Pushkarev, M.F. Soil Erosion (Translation from English); Kolos: Moscow, Russia, 1984; 415p. (In Russian)

11. Taisaev, T.T. Aeolian Processes in the Olkhon and on about. In Olkhon (Western Transbaikalia); Academy of Sciences of the USSR: Saint Petersburg, Russia, 1982; Volume 265, pp. 948-951. (In Russian)

12. Bazhenova, O.I.; Lyubtsova, E.M.; Ryzhov, Y.V.; Makarov, S.A. Spatio-Temporal Analysis of the Dynamics of Erosion Processes in the South of Eastern Siberia; Nauka: Novosibirsk, Russia, 1997; 208p. (In Russian)

13. Chichagov, V.P. The 1980 Hurricane in Eastern Mongolia and Characteristics of Aeolian Relief Formation in Central and East Asia; Institute of Geography RAS: Moscow, Russia, 1998; 205p. (In Russian)

14. Lopatin, D.V.; Skovitina, T.M. Denudationary Morpholithogenesis of the Olkhon region (St. 2. Small Upland). Geomorphology 2011, 85-90. (In Russian)

15. Ufimtsev, G.F.; Skovitina, T.M.; Filinov, I.A.; Schetnikov, A.A. Relief Features of the Olkhon Region. Geogr. Nat. Resour. 2010, 4, 56-61.

16. Agafonov, B.P. Windflow from Lake Baikal, Dokl. RAS 2002, 382, 688-691. (In Russian)

17. Agafonov, B.P. Stilted Trees at Baikal-Indicators of Anthropogenic Lithodynamic Processes. In Relief and Man; Nauchnyi Mir: Moscow, Russia, 2007; pp. 157-165. (In Russian)

18. Koroleva, G.P.; Kosov, A.A.; Geletii, V.F.; Vologina, E.G. Geochemical Characteristics of the Aeolian Material of the Region of the Academic Ridge of Lake Baikal and its Sources. Geol. Geophys. 2001, 42, 258-266. (In Russian)

19. Vologina, E.G.; Potemkin, V.L. Characteristics of Aeolian transfer in winter in the Area of the Academic Ridge of Lake Baikal. Geol. Geophys. 2001, 42, 254-257. (In Russian)

20. Vika, S.; Ovchinnikov, G.I.; Snytko, V.A.; Shchipek, T. Aeolian Facies of the Eastern Coast of Baikal, Irkutsk; Publishing House of the Institute of Geography SB RAS: Barnaul, Russia, 2002; 56p. (In Russian)

21. Vika, S.; Imethenov AB Ovchinnikov, G.I. Aeolian Processes of the Coasts at the Bay Proval on Baikal, Irkutsk; Publishing House of the Institute of Geography of the SB RAS: Barnaul, Russia, 2006; 56p.

22. Obruchev, V.A. The Question of the Origin of Loess - in Defence of the Aeeolian Hypothesis; Izvestiya Tomskogo Tekhnologicheskago Instituta: Tomsk, Russia, 1911; Volume 33, 38p. (In Russian)

23. Kryukov, N.A. Western Transbaikalia from the Agricultural Perspective; Tipografiya V. Kirshbauma: St. Petersburg, Russia, 1896; 233p. (In Russian)

24. Antoshchenko-Olenev, I.V. The History of Natural Situations and Tectonic Movements in the Late Cenozoic of Western Transbaikalia; Nauka: Novosibirsk, Russia, 1982; 156p. Available online: http:/ / www.geokniga.org/bookfiles/geokniga-istoriya-prirodnyh-obstanovok-i-tektonicheskihdvizheniy-v-pozdnem-kaynozoe-za.pdf (accessed on 25 November 2018). (In Russian)

25. Shchipek, T.; Vika, S.; Snytko, V.A.; Buyantuev, A.B. Facies of the Waving Sands of the Chikoi-Selenginsky Interfluve in the Western Transbaikalia; Irkutsk: Publishing House of the Institute of Geography of the SB RAS: Barnaul, Russia, 2000; 72p. (In Russian)

26. Ryzhov, B.I. Aeolian-Deluvial Deposits of the Environs of the City of Chita. In Modern and Quaternary Continental Lithogenesis; Nauka: Moscow, Russia, 1966; pp. 190-197. (In Russian)

27. Strelnikov, V.G.; Ostroumov, V.M. Salt Dust Storms in the Aginsk Steppe. In Soil Cover of Transbaikalia, Ways to Improve Its Fertility and Sustainable Use; Ostroumov, V.M., Ed.; Publishing House of Botan. Society: Chita Oblast, Russia, 1978; pp. 140-141. (In Russian)

28. Shamsutdinov, V.K. Archaeological Sites and the Paleogeography of the Holocene of the Torei Depression (Southeastern Transbaikalia). In Siberia and its Neighbors in Antiquity; Nauka: Novosibirsk, Russia, 1970; pp. 284-289. (In Russian)

29. Voloshin, A.L. On the Monitoring of Modern Relief-Forming Processes of the Intermountain Basins of the Transbaikalian Type. Geogr. Nat. Resour. 2000, 1, 68-70. (In Russian)

30. Chichagov, V.P. Aeolian Relief of the Eastern Mongolia; Institute of Geography Russian Academy of Science: Moscow, Russia, 1999; 270p. (In Russian)

31. Bazhenova, O.I.; Cherkashina, A.A.; Kobylkin, D.V.; Makarov, S.A.; Vershinin, K.E. Geomorphological Holocene Events as Deduced From Lithological Records of the Fluvial Basins of Dauria. Geogr. Nat. Resour. 2017, 38, 154-164. [CrossRef] 
32. Bazarova, V.B.; Mokhova, L.M.; Klimin, M.A.; Orlova, L.A.; Bazarov, K.Y. Climate Changes and Sedimentation Conditions in the Mid-late Holocene in the Southeastern Transbaikalia. Geol. Geophys. 2008, 49, 1294-1303. (In Russian)

33. Ptitsyn, A.B.; Reshetova, S.A.; Babich, V.V.; Darin, A.V.; Kalugin, I.A.; Ovchinnikov, D.V.; Panizzo, V.; Myglan, V.S. Aridization Trends in Transbaikalia over the Past 1900 Years. Geogr. Nat. Resour. 2010, 31, 144-147. (In Russian) [CrossRef]

34. Bazhenova, O.I.; Martyanova, G.N. Formation of extremal morphoclimatic situations in the south of Siberia. Geogr. Nat. Resour. 2004, 4, 87-94.

(C) 2019 by the authors. Licensee MDPI, Basel, Switzerland. This article is an open access article distributed under the terms and conditions of the Creative Commons Attribution (CC BY) license (http://creativecommons.org/licenses/by/4.0/). 